\title{
Phytochemical and Toxicity Assay of Meistera chinensis Fruit Extract: The Endemic Plant of Southeast Sulawesi
}

\author{
S. A. Tee ${ }^{1 *}$, Musdalipah ${ }^{1}$, Karmilah $^{1}$, I Sahidin ${ }^{2}$, A. Fristiohady ${ }^{3}$, \\ A.W. M. Yodha ${ }^{1}$ \\ ${ }^{1}$ A Pharmacy Study Program, Politeknik Bina Husada Kendari, Southeast Sulawesi, Indonesia \\ ${ }^{2}$ Pharmacognosy and Phytochemistry, Faculty of Pharmacy, Halu Oleo University, Kendari, Southeast \\ Sulawesi, Indonesia. \\ ${ }^{3}$ Department of Pharmacology and Clinical Pharmacy, Faculty of Pharmacy, Halu Oleo University, Kendari, \\ Southeast Sulawesi, Indonesia. \\ *e-mail: musdalipahapt@gmail.com
}

\begin{abstract}
Meistera chinensis is one of the endemic plants of Southeast Sulawesi from the Zingiberaceae family which has a large number of species and an interesting potential to be developed as a source medicine. However, there is no report on neither chemical contents nor biological activities of the plant. The aim of this study was to identify the phytochemicals by Thin-Layer Chromatography (TLC) and toxicity of Meistera chinensis fruit using the Brine Shrimp Lethality Test (BSLT). The fruit of Meistera chinensis was macerated with ethanol $95 \%$ for $3 \times 24 \mathrm{~h}$, and the solvent was evaporated in a vacuum. The toxicity of the extract was determined by the brine shrimp lethality test use with concentrations of 10,100,250,500, and $750 \mu \mathrm{g} / \mathrm{mL}$ according of death of Artemia Salina larvae and calculated by determining the $\mathrm{LC}_{50}$ score. The results showed that the phytochemical screening by UV-Vis $254 \mathrm{~nm}$ and $366 \mathrm{~nm}$ indicates presence phenolics, flavonoids, steroids, terpenoids, alkaloids, and saponins. In the BSLT assay of ethanol extracts of the Meistera chinensis fruit were found highly toxic to the Artemia salina with $\mathrm{IC}_{50}$ values of $5.02 \pm 1.11 \mathrm{mg} /$ $\mathrm{mL}$ and control $2.26 \pm 0.60 \mathrm{mg} / \mathrm{mL}$. These findings indicate that the extract of Meistera chinensis fruit is very potential to be used as a medicinal plant and can be developed as a natural anticancer product..
\end{abstract}

Keywords: Toxicity, Meistera chinensis fruit, endemic plant, herbal medicine

\section{INTRODUCTION}

Today, herbal plants have been widely used around the world as a form of health care. Herbs play an important role in modern medicine. Medicinal plants sustainably maintain human health for many years [1]. the use of plant secondary metabolites has been widely used to cure various diseases. Traditional medicine is clinically effective and is preferred because it has fewer side effects than drugs of synthetic origin [2,3]. Zingiberaceae is an important plant family that has been reported with high potential biological activity that can treat various diseases such as cancer, diabetes, ulcers, and neurological diseases [4].

Zingiberaceae has a large number of species and still requires studies to reveal its chemical content and pharmacological activity. Several new generations were discovered by Conamomum, Meistera, and Wurfbainia in the newly discovered Zingiberaceae family. Therefore, it is important to determine the medicinal potency of plants by intensifying studies on medicinal plants on an ongoing basis [5].

Meistera chinensis is a species of the Zingiberaceae group, which is endemic to Southeast Sulawesi, is widespread, and is very much found in Konawe Regency. Empirically, Meistera chinensis is used as a flavor enhancer in food, aches, and increases body immunity. The latest research of Meistera chinensis fraction suggest that its has antioxidant and anticancer activity [6].

The safety of potential toxic effects in drug development is important to ensure their use. The low toxicity and clinical effectiveness of natural compounds are one of the aims of the researchers to obtain plant biological activity [6]. Toxicity testing is the first step in drug safety parameters before it becomes a drug product that can be used in humans.

Nowadays, health problems are increasing in line with the development of the disease. The problem of health service costs is increasing, so it is necessary to think about increasing product efficiency 
[7]. The use of herbs as traditional medicine is growing along with increasing exploration data on the types of natural ingredients that can be used to prevent and treat disease [8]. Therefore, from a public health perspective, it is important to know about the recipe and dosage of plants used, especially in terms of toxicity, composition, special properties for patient protection and safety [9]. One of the initial methods for cytotoxic testing is the Brine Shrimp Lethality Test (BSLT). BSLT is a method that is widely used to search for new anticancer compounds derived from plants. The BSLT method has been shown to correlate with anticancer activity. Also, this method is easy to work with, cheap, fast, and quite accurate [10]. In this study, our objective was to investigate, phytochemicals, and toxicity of Meistera chinensis fruit using the Brine Shrimp Lethality Test (BSLT).

\section{MATERIALS AND METHODS}

\subsection{Materials}

The Plant material was collected in February 2020 in Konawe Regency, Southeast Sulawesi. The plant was authenticated by The Indonesian Institute of Sciences, Indonesian. Voucher specimens have been preserved in the herbarium of The Department of Botany, Indonesian Institute of Sciences. Fresh fruit is washed under running water, then cut into small pieces, then dried at $40{ }^{\circ} \mathrm{C}$ and protected from the sun for 4 days.

\subsection{Extraction method}

The dried sample was refined by using the blender. Refined fruit was weighed approximately $3,000 \mathrm{~g}$ then macerated with ethanol $95 \%$, placed on a shaker for 3-5 days while occasionally stirred. Afterward, The extract extract liquid was filtered and evaporated using a rotary evaporator. The crude extract was weighed and obtained $150 \mathrm{~g}$.

\subsection{Phytochemicals screening by Thin-Layer Chromatography (TLC)}

Phytochemical screening by TLC was used to detect the presence of secondary metabolites such as phenols and tannins, flavonoids, steroids, alkaloids, terpenoids, [11]:

\subsubsection{Test for phenols and tannins.}

$0.2 \mathrm{~g}$ of the extract were dissolved in $2 \mathrm{~mL}$ of distilled water and heated using a water bath at $95{ }^{\circ} \mathrm{C}$. then a few drops are added concentrated sulfuric acid followed by a few drops of $5 \%(\mathrm{w} / \mathrm{v})$ ferric chloride. Tannins are indicated by the formation of a blue, black, green precipitate

\subsubsection{Test for flavonoids.}

$0.5 \mathrm{~g}$ of the extract was dissolved in $2 \mathrm{~mL}$ of methanol and heated in a separate water bath. then add a little magnesium powder to the mixture and a few drops of hydrochloric acid afterward. An intense yellow color was formed which turned colorless on the addition of a few drops of diluted acid which indicated the presence of flavonoids

\subsubsection{Test for a steroid.}

About 0,5 gr the crude extract was mixed with $2 \mathrm{~mL}$ of chloroform and concentrated $\mathrm{H}_{2} \mathrm{SO}_{4}$ was added sidewise. Steroids are indicated by the presence of a red colour in the layer of chloroform.

\subsubsection{Test for terpenoids.}

About 0,5 gr the crude extract was dissolved in $2 \mathrm{~mL}$ of chloroform and evaporated to dryness. To this, $2 \mathrm{~mL}$ of concentrated $\mathrm{H}_{2} \mathrm{SO}_{4}$ was added and heated for about 2 minutes. A grayish color indicated the presence of terpenoids.

\subsubsection{Test for alkaloids.}

About 0,5 gr the crude extract was mixed with $2 \mathrm{~mL}$ of $1 \% \mathrm{HCl}$ and heated gently. Mayer's reagents were then added to the mixture. The turbidity of the resulting precipitate was taken as evidence for the presence of alkaloids.

\subsubsection{Test for saponins.}

Abaout $0.1 \mathrm{~g}$ of extract was added. $2 \mathrm{~mL}$ of distilled water were added separately and stirred in a test tube for 15 minutes. the presence of saponins is indicated by the formation of foam.

\subsection{Toxicological Evaluation Brine Shrimp Lethality Assay}

The method available by Meyer et al. [10] was adopted for testing the toxicity of ethanol extraction. Artemia salina larvae are hatched in a transparent container filled with sea water. Prepared a light bulb with a power of 40-60 watts for hatching at a temperature within $25-30^{\circ} \mathrm{C}$. Oxygen is supplied using a blower. Shrimp larvae were prepared with a 48 hour hatching period. The concentrations used in the BSLT were $10 \mu \mathrm{g} / \mathrm{mL}, 100 \mu \mathrm{g} / \mathrm{mL}, 250 \mu \mathrm{g} /$ $\mathrm{mL}, 500 \mu \mathrm{g} / \mathrm{mL}, 750 \mu \mathrm{g} / \mathrm{mL}$, and negative control. A stock solution was made of $5 \mathrm{mg}$ of extract dissolved in $5 \mathrm{~mL}$ of ethanol for $1,000 \mathrm{ppm}$. The stock solution is pipetteed and put into the vial. Each concentration was repeated 3 times. In the vial, $1 \%$ DMSO was added to the air-insoluble fraction. Five milliliters of seawater are added to the vial. All processes were carried out by adding samples to the vial for concentrations of $10 \mu \mathrm{g} / \mathrm{mL}, 100 \mu \mathrm{g} / \mathrm{mL}$, $250 \mu \mathrm{g} / \mathrm{mL}, 500 \mu \mathrm{g} / \mathrm{mL}$, and $750 \mu \mathrm{g} / \mathrm{mL}$. The control has no samples in it. Ten Artemia larvae were added to each vial. Observations were made for 24 hours. The toxicity test was determined according to the number of death larvae. The toxicity test was assessed by determining the $\mathrm{LC}_{50}$ score. To obtain $\mathrm{LC}_{50}$, the mortality rate of larvae after 24 hours of exposure was assessed first.

$\%$ mortality $=$ Total larvae mortality/Total larvae $x$ $100 \%$

The toxicity level of a compound is classified according to Mayer [10] classification. $\mathrm{LC}_{50}$ score in the range of $\leq 30 \mu \mathrm{g} / \mathrm{mL}$ is defined as highly toxic. $\mathrm{LC}_{50}$ in range of $>30-1000 \mu \mathrm{g} / \mathrm{mL}$ is classified as medium toxic, while $>1,000 \mu \mathrm{g} / \mathrm{mL}$ as low toxic. 


\section{RESULT AND DISCUSSION}

\subsection{Sample preparation and extraction}

The preparation of the research sample was made in the form of simplicia and extracted using a recurring maceration method with $96 \%$ ethanol as a solvent. The results of the preparation and extraction can be seen in Table 1 .

Table 1. Results of preparation, extraction, and yield values of the Meistera chinensis fruit extract.

\begin{tabular}{|c|c|c|c|c|}
\hline $\begin{array}{c}\text { Fresh } \\
\text { sample }(\mathrm{g})\end{array}$ & $\begin{array}{c}\text { Dry simplisia } \\
(\mathrm{g})\end{array}$ & $\begin{array}{c}\text { Liquid } \\
\text { extract }(\mathrm{mL})\end{array}$ & $\begin{array}{c}\text { extract } \\
(\mathrm{g})\end{array}$ & $\begin{array}{c}\text { Yield } \\
(\%)\end{array}$ \\
\hline 5,000 & 2,998 & 22,485 & 150 & 5 \\
\hline
\end{tabular}

Based on table 1, the thick extract obtained was $150 \mathrm{~g}$ and the yield value was $5 \%$. The yield value was calculated by comparing the weight of the thick extract against the amount of simplicia powder used in the extraction process.

\subsection{Identification of a chemical compound by Thin-Layer Chromatography (TLC)}

In general, chromatograms are made on silica gel with various types of mobile phases according to the chemical content group as the target of the analysis.
Evaluation can be done by documenting photos of the results of a chromatogram with the appropriate reagent. Observations can be made of $254 \mathrm{~nm}$ and $365 \mathrm{~nm}$ or at other wavelengths that are specific to a known component [12]. The results of the chemical compound can be seen in Table 2 .

Table 2. Phytochemical evaluation of the Meistera chinensis fruit extract by TLC

\begin{tabular}{|c|c|c|c|c|c|}
\hline No & Identification & Eluent & Reagent & $\begin{array}{l}\text { Result of chromatogram } \\
\text { (A=UV } 254 \mathrm{~nm}, \mathrm{~B}=\mathbf{U V} \\
\mathbf{3 6 6} \mathbf{~ n m}, \mathrm{C}=\text { Reagent) }\end{array}$ & Result \\
\hline 1 & Phenolics & $\begin{array}{c}n \text {-heksan:ethyl } \\
\text { acetate } \\
(4: 6)\end{array}$ & $\mathrm{FeCl}_{3}$ & $\infty$ & + \\
\hline 2 & Flavonoids & $\begin{array}{c}\text { kloroform:aceton } \\
(9: 1)\end{array}$ & $\mathrm{NaOH}$ & 0 & + \\
\hline 3 & Alkaloids & $\begin{array}{c}n \text {-heksan:ethyl } \\
\text { acetate } \\
(7: 3)\end{array}$ & Dragendroff & b & + \\
\hline 4 & Steroids & $\begin{array}{c}n \text {-heksan:ethyl } \\
\text { acetate } \\
(9: 1)\end{array}$ & $\mathrm{H}_{2} \mathrm{SO}_{4}$ & & + \\
\hline 5 & Saponins & $\begin{array}{c}n \text {-heksan:ethyl } \\
\text { acetate } \\
(9: 1)\end{array}$ & $\mathrm{H}_{2} \mathrm{SO}_{4}$ & $\begin{array}{r}\Theta \\
8\end{array}$ & + \\
\hline
\end{tabular}

(+): Presence; (-): Absence 
Based on table 2, phytochemical evaluation, the results showed that Meistera chinensis fruit extract contains several secondary metabolites including phenolics, flavonoids, alkaloids, steroids, terpenoids, and saponins. Several secondary metabolites including triterpenoids and flavonoids are known to have anticancer properties. Today, medicinal plants of Zingiberaceae have become the source of the drug [13]. Plants contain a variety of chemical compounds such as steroids, alkaloids, terpenoids, flavones, phenols, etc that are responsible for many pharmacological properties [14]. In the future, the presence of these metabolites can be used as an indication of the potency of Meistera chinensis fruit as a medicine plant.

\subsection{Toxicological Evaluation Brine Shrimp Lethality Assay}

The toxicity of the Meistera chinensis fruit extract using the BSLT method. The mortality percentage and $\mathrm{LC}_{50}$ of ethanolic extract of Meistera chinensis are shown in Table 3.

Table 3. Result of Toxicological Evaluation Brine Shrimp Lethality Assay of the Meistera chinensis fruit extract

\begin{tabular}{|c|c|c|c|c|c|c|c|c|}
\hline $\begin{array}{c}\text { Concentratio } \\
n\end{array}$ & $\begin{array}{c}\log 10 \\
\text { Kons }\end{array}$ & $\begin{array}{c}\text { replicatio } \\
\mathrm{n}\end{array}$ & $\begin{array}{l}\text { Total of } \\
\text { Larvae }\end{array}$ & $\begin{array}{c}\text { Larvae } \\
\text { mortalit } \\
\text { y }\end{array}$ & $\begin{array}{c}\% \\
\text { Mortality }\end{array}$ & $\begin{array}{c}\text { Rate \% } \\
\text { Mortalitas }\end{array}$ & Probit & $\begin{array}{l}\mathrm{LC}_{50} \\
(\mathrm{ppm})\end{array}$ \\
\hline 0 & 0 & 1 & 20 & 0 & 0 & \multirow{3}{*}{0} & \multirow{3}{*}{0} & \multirow{18}{*}{$\begin{array}{c}5.02 \pm 1.1 \\
1\end{array}$} \\
\hline & & 2 & 20 & 0 & 0 & & & \\
\hline & & 3 & 20 & 0 & 0 & & & \\
\hline 10 & 1 & 1 & 20 & 15 & 75 & \multirow{3}{*}{75} & \multirow{3}{*}{5.67} & \\
\hline & & 2 & 20 & 16 & 80 & & & \\
\hline & & 3 & 20 & 14 & 70 & & & \\
\hline \multirow[t]{3}{*}{100} & 2 & 1 & 20 & 18 & 90 & 86.67 & 6.08 & \\
\hline & & 2 & 20 & 18 & 90 & & & \\
\hline & & 3 & 20 & 16 & 80 & & & \\
\hline \multirow[t]{3}{*}{250} & 2.31 & 1 & 20 & 20 & 100 & 100 & 8.09 & \\
\hline & & 2 & 20 & 20 & 100 & & & \\
\hline & & 3 & 20 & 20 & 100 & & & \\
\hline 500 & 2.69 & 1 & 20 & 20 & 100 & \multirow{3}{*}{100} & \multirow{3}{*}{8.09} & \\
\hline & & 2 & 20 & 20 & 100 & & & \\
\hline & & 3 & 20 & 20 & 100 & & & \\
\hline \multirow[t]{3}{*}{750} & 2.88 & 1 & 20 & 20 & 100 & \multirow{3}{*}{100} & \multirow{3}{*}{8.09} & \\
\hline & & 2 & 20 & 20 & 100 & & & \\
\hline & & 3 & 20 & 20 & 100 & & & \\
\hline
\end{tabular}

Based on table 3, toxicity testing of the Meistera chinensis fruit extract obtained an $\mathrm{LC}_{50}$ value obtained of $5.02 \pm 1.11 \mathrm{mg} / \mathrm{mL}$ and included in the category highly toxic $(\leq 30 \mathrm{ppm})$. The toxicity level of a compound is classified according to Mayer [9] classification. $\mathrm{LC}_{50}$ score in the range of $\leq 30 \mu \mathrm{g} / \mathrm{mL}$ is defined as highly toxic. Toxicity testing is a common method that can be used to discover new types of drugs. It indicates that substances or chemicals can harm humans or animals. The BSLT technique is a method for identifying the toxicity properties of any chemical [15].
Nowadays, discovering the development of chemicals as an invented method for the production of synthetic drugs, the discovery of new compounds from medicinal plants to treat several diseases is also growing. Generally, the plants of the Zingiberaceae family have a secondary metabolism with pharmacological activity. Several studies have reported several medicinal plants that act as cytotoxic. In the last 10 years, various Zingiberaceae studies have been continuously developed to find new drug ingredients [15]. 


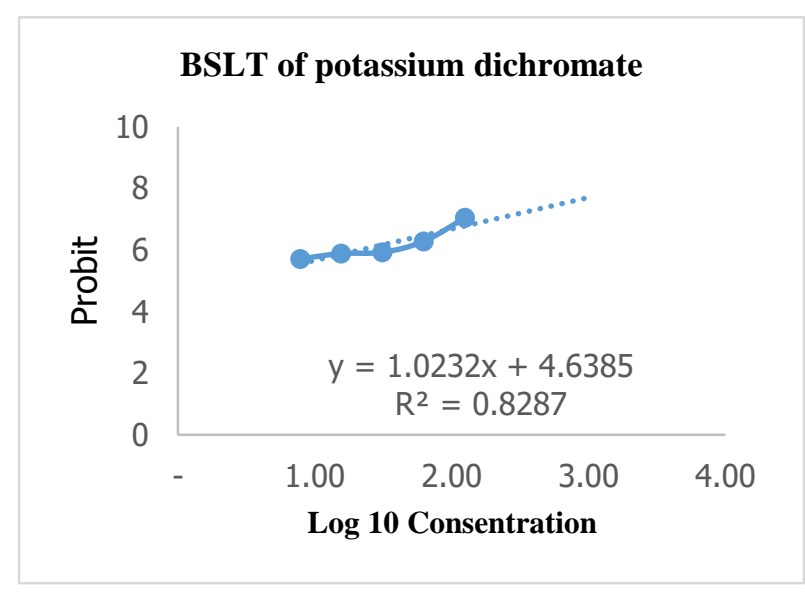

(a)

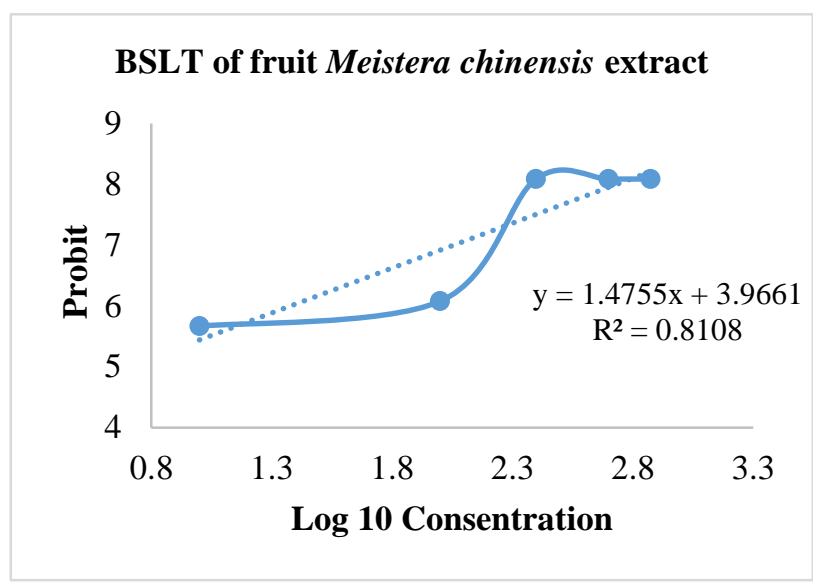

(b)

Fig. 1. Artemia Salina Leach mortality

(a). Control Positif; (b). Fruit of Meistera chinensis extract

Figure 1 shows that each increase in extract concentration, the mortality rate of shrimp larvae increases. The mortality of shrimp larvae by the extract was not much different from the positive control for potassium dichromate $\left(\mathrm{LC}_{50}=2.26 \pm 0.60 \mathrm{mg} / \mathrm{mL}\right)$. This means that the higher the concentration of a given substance, the greater the number of shrimp larvae that die. The highest mortality rate occurred at $250-750 \mu \mathrm{g}$ / $\mathrm{mL}$ is $100 \%$. In other words, the higher the concentration given, the greater the poisoning it causes. Mortality and survival over some time of exposure are specific effects in acute toxicity tests with long-term exposure.

The mortality rate of larvae was not only caused by the concentration of the fruit Meistera chinensis extract given against Artemia salina larvae, but also caused by the presence of secondary metabolites of phenolic compounds such flavonoid and phenolic [17]. Polyphenol compound affects the mortality rate of Artemia salina larvae Flavonoids as antioxidants, through the mechanism of activating the apoptotic pathway of cancer cells. The mechanism of cell apoptosis in this theory is due to DNA fragmentation. This fragmentation begins with the release of the proximal DNA chain by reactive oxygen compounds such as hydroxyl radicals. Another effect is flavonoids as inhibitors of tumor/cancer proliferation, one of which is by inhibiting protein kinase activity, thereby inhibiting the signal transduction pathway from the membrane to the nucleus cells. Flavonoids inhibit tyrosine kinase receptor activity because the increased activity of tyrosine kinase receptors plays a role in the growth of cancer cells [18].

\section{CONCLUSION}

The phytochemical screening of ethanolic extract of meistera chinensis fruit revealed the presence of the following compounds: phenolics, flavonoids, steroids, terpenoids, alkaloids, and saponins. The BSLT test showed that ethanolic extracts of the Meistera chinensis fruit were found highly toxic. From this, it can be concluded that the Meistera chinensis fruit is very potential to be used as a medicinal plant and can be developed as a natural anticancer product.

\section{ACKNOWLEDGMENTS}

The authors gratefully acknowledge the financial support of the Ministry of Research, Technology, and Higher Education of the Republic of Indonesia for "Penelitian Kerja Sama Perguruan Tinggi (PKPT) 2020 No. 231/SP2H/LT/DRPM/2019.

\section{REFERENCES}

[1] Bourhia M, Lahmadi A, Achtak H, Touis A, Elbrahmi J, Ullah R, et al. "Phytochemical analysis and toxicity study of aristolochia paucinervis rhizomes decoction used in moroccan alternative medicine: Histopathological and biochemical profiles". Evidence-based Complement Altern Med. 2019.

[2] Awaad, A.S., R.M. El-meligy, S.A. Qenawy, A.H. Atta and G.A. Soliman,. "Anti-inflammatory, antinociceptive and antipyretic effects of some desert plants". $J$. Saudi Chem. Soc., vol.15, pp. 367-373, 2015.

[3] Liu, Q., X. Meng, Y. Li, C.N. Zhao, G.Y. Tang and H.B. Li, 2017. "Antibacterial and antifungal activities of spices". Int. J. Mol. Sci., vol. 18, 2017.10.3390/ijms18061283. 
[4] Kress, W.J., A.Z. Liu, M. Newman and Q.J. $\mathrm{Li}$, "The molecular phylogeny of Alpinia (Zingiberaceae): A complex and polyphyletic genus of gingers". Am. J. Bot., vol. 92, pp. 167-178, 2005.

[5] De Boer H, Newman M, Poulsen A D, Jane Droop a., Fér T, Hiền LTT, "Convergent morphology in alpinieae (Zingiberaceae): Recircumscribing amomum as a monophyletic genus". Taxon, vol. 67, no.1, pp 6-36, 2018.

[6] Musdalipah, M., Tee, S. A., Karmilah, K., Sahidin, S., Fristiohady, A., \& Yodha, A. W. "M. Total Phenolic and Flavonoid Content, Antioxidant, and Toxicity Test with BSLT of Meistera chinensis Fruit Fraction from Southeast Sulawesi". Borneo Journal of Pharmacy, vol. 4, no.1, pp 6-15, 2021, https://doi.org/10.33084/bjop.v4i1.1686

[7] Musdalipah and Tee SA. "Analisis efektivitas biaya obat alprazolam dan diazepam pada pasien depresi di rumah sakit jiwa Provinsi Sulawesi Tenggara". J Ilmiah Ibnu Sina. Vol. 8, no.2, pp. 252-260, 2018.

[8] Musdalipah; Karmilah. "Efektivitas Ekstrak Daun Cabai Rawit (Capsicum frutescents L.) Sebagai Penumbuh Rambut Terhadap Hewan Uji Kelinci (Oryctolagus cuniculus)". Riset Informasi Kesehatan, vol. 7, no.1, pp. 83-8, 2018.

[9] Angone SA, Mewono L, Boukandou Mounanga M, Medzegue S, Ella Mendene HF, Mba Ndong JG, et al. "Phytochemical screening and cytotoxicity studies of Chrysophyllum pruniforme Pierre ex Engl. Barks". Pharmacognosy Res, vol. 5, no.3, pp. 195-9, 2015.

[10] Meyer, B.N., Ferrigni, N.R., Putnam, J.E., Jacobsen, L.B., Nichols, D.E., dan McLaughin, J.L, "Brine Shrimp: A Convenient General Bioassay for Active Plant Constituent", Planta Medica, vol. 45, pp.31-34, 1982

[11] Yadav R N S and Agarwala, "Phytochemical analysis of some medicinal plants". $J$.
Phytol, vol. 3, no.12, pp. 10-14, 2011.

[12] Departemen Kesehatan, "Parameter Standar Umum Ekstrak Tumbuhan Obat", Departemen Kesehatan Republik Indonesia, Indonesia, 2002.

[13] Barath M, Aravind J, Sivasamy R. "Investigation of Antimicrobial activity and Chemical Constituents of Eragrostiscynosuroides by GC-MS". Research Journal of Pharmacy and Technology. Vol. 9, no. 3, pp. 267, 2016.

[14] Kumar V, Sharma A, Kaur H, Thukral AK, Bhardwaj R. "Phytochemical profiling of the leaves of Chenopodium and Polygonum using GC-MS". Research Journal of Pharmacy and Technology, vol. 8, no.12, pp.1629, 2015

[15] Saragih G, Tamrin, Marpongahtun, Nasution DY, Abdillah. "Phytochemical screening and toxicity of ethanolic extract of mangrove (Rhizophora mucronata) leaves from Langsa, Aceh Timur". Rasayan J Chem, vol. 13, vol. 1, pp. 476-80, 2020.

[16] Rahman NH, Vigneswari S, Ahmad A, Mohamad H, Muhammad TS. "Cytotoxic effects and evidence of apoptosis from avecenniaalba extracts on human breast cancer cell line (MCF-7)". Journal of Sustainability Science and Management, vol. 12, no.2, pp. 80-88, 2017.

[17] Rasyid, M., H, Y., \& Angraeni, L. Toxicity "Test LC 50 of Pineung Nyen Teusalee Seeds ( Areca catechu ) Extract by Brine Shrimp Lethality Test ( BSLT ) Methode Toxicity Test LC 50 of Pineung Nyen Teusalee Seeds ( Areca catechu ) Extract by Brine Shrimp Lethality Test ( BSLT ) Methode". IOP Conference Series: Earth and Environmental Science, vol. 515, pp. 16, 2020.

[18] Woo, H. D dan Kim, J. "Dietary Flavonoid Intake and Risk of Stomach and Colorectal Cancer". World Journal of Gastroenterology, vol. 7, pp.1011-1019, 2013. 